Tersedia online di: http://ejournal-balitbang.kkp.go.id/index.php/bawal
e-mail:bawal.puslitbangkan@ gmail.com
BAWAL WIDYA RISET PERIKANAN TANGKAP
Volume 11 Nomor 2 Agustus 2019
p-ISSN: 1907-8226
e-ISSN: 2502-6410
BAWAL Nomor Akreditasi Kementerian RISTEKDIKTI: 21/E/KPT/2018

\title{
OPTIMALISASI PCR IKAN TONGKOL KRAI (Auxis thazard) DAN LISONG (Auxis rochei) PADAANALISIS KERAGAMAN GENETIK
}

\section{PCR OPTIMIZATION OF FRIGATE AND BULLET TUNA ON GENETIC DIVERSITY ANALYSIS}

\author{
Raymon R. Zedta*1 dan Bram Setyadji ${ }^{1}$ \\ ${ }^{1}$ Loka Riset Perikanan Tuna, Bali, J1. Mertasari No. 140 Br Suwung Kangin, Sidakarya, Denpasar Bali, 80224, Indonesia \\ Teregistrasi I tanggal: 29 September 2019; Diterima setelah perbaikan tanggal: 09 Januari 2020; \\ Disetujui terbit tanggal: 10 Januari 2020
}

\begin{abstract}
ABSTRAK
Ikan tongkol lisong dan krai merupakan salah satu jenis tuna yang berperan nyata untuk usaha perikanan tangkap di Indonesia. Pengelolaan sumberdaya ikan tersebut harus selalu dapat dilakukan untuk menjaga tingkat pemanfaatannya supaya tidak lebih tangkap. Kajian keragaman genetik merupakan salah satu teknik dalam pengelolaan pemanfaatan sumberdaya perikanan dengan cara mengetahui tingkat keragaman genetik pada suatu struktur populasi. Kajian keragaman genetik ini diharapkan dapat menjadi basis kajian stok dan opsi dalam pengelolaan sumberdaya perikanan tongkol agar pemanfaatannya dapat dilakukan secara berkelanjutan. Awal mula analisis keragaman genetik dilakukan dengan memperbanyak DNA secara in vitro menggunakan teknik PCR (Polymerase Chain Reaction). Keberhasilan proses PCR dipengaruhi oleh beberapa faktor seperti suhu dan waktu penempelan oligonukleotida primer. Berdasarkan hal tersebut, penelitian ini bertujuan untuk mengetahui suhu dan waktu optimal pada primer Aro2-38. Sampel penelitian diperoleh dari hasil tangkapan pukat cincin yang didaratkan di PPN Palabuhanratu, Jawa Barat. Optimasi PCR menggunakan 12 suhu dan 2 waktu penempelan yang berbeda yaitu : $52^{\circ} \mathrm{C} ; 52,8^{\circ} \mathrm{C} ; 54^{\circ} \mathrm{C} ; 55,5^{\circ} \mathrm{C} ; 57,2^{\circ} \mathrm{C} ; 59,1^{\circ} \mathrm{C} ; 60,9^{\circ} \mathrm{C} ; 62,8^{\circ} \mathrm{C} ; 64,5^{\circ} \mathrm{C}$; $65,9^{\circ} \mathrm{C} ; 67,2^{\circ} \mathrm{C}$ dan $68^{\circ} \mathrm{C}$, dan suhu penempelan 30 dan 15 detik. Hasil analisis menunjukkan bahwa produk PCR optimum (menghasilkan pita alel DNA) pada ikan tongkol krai berhasil waktu penempelan 30 detik dengan rentang suhu $52-54^{\circ} \mathrm{C}$. Sedangkan pada sampel ikan tongkol lisong, produk PCR yang optimum muncul pada waktu penempelan 15 dan 30 detik, dengan rentang suhu $52-60,9^{\circ} \mathrm{C}$.
\end{abstract}

Kata Kunci: Tongkol lisong; tongkol krai; keragaman genetik; polymerase chain reaction

\section{ABSTRACT}

Frigate and bullet tuna constitute one of tuna species that plays a significant role in Indonesian fishing business. Management of fisheries resources must always be done to maintain the level of utilization so that it is not excessive. Genetic study is one of techniques in managing fisheries resource utilization by knowing the level of genetic diversity in a population structure. This genetic diversity study is expected to be the basis and option in the management of tuna fishing resources so that their utilization can be carried out sustainably. Genetic diversity analysis is start by multiplying fish DNA using PCR (Polymerase Chain Reaction) technique. PCR process is influenced by several factors such as temperature and time of primary oligonucleotide attachment. This study aims to determine the optimal temperature and time in primers Aro2-38. The research sample was obtained from the catch of purse seine landed in PPN Palabuhanratu, West Java. PCR optimization uses 12 temperatures and 2 different annealing times: $52^{\circ} \mathrm{C} ; 52.8^{\circ} \mathrm{C} ; 54^{\circ} \mathrm{C} ; 55,5^{\circ} \mathrm{C} ; 57.2^{\circ} \mathrm{C} ; 59.1^{\circ} \mathrm{C} ; 60.9^{\circ} \mathrm{C} ; 62.8^{0} \mathrm{C}$; $64,5^{\circ} \mathrm{C} ; 65,9^{\circ} \mathrm{C} ; 67.2^{\circ} \mathrm{C}$ and $68^{\circ} \mathrm{C}$, and the annealing times are 30 and 15 seconds. Theresults of the analysis showed that the optimum PCR product (obtain DNA allele bands) on the frigate tuna primer was successfully annealed at 30 seconds with a temperature range of $52-54^{\circ} \mathrm{C}$. While in the sample of bullet tuna, the optimum PCR product appeared at the time of annealing at 15 and 30 seconds, with a temperature range of 52-60.9 ${ }^{\circ} \mathrm{C}$.

Keywords: Bullet tuna; frigate tuna; genentic diversity; polymerase chain reaction 


\section{PENDAHULUAN}

Keragaman genetik merupakan tingkatan paling rendah dalam keberagaman hayati dan merupakan kunci penting bagi suatu jenis mahluk hidup seperti ikan misalnya untuk bertahan hidup sampai generasi yang akan datang. Krisis biodiversitas atau keragaman hayati dimulai dari semakin menurunnya tingkat keragaman genetik suatu jenis mahluk hidup. Pada suatu populasi, keragaman genetik merupakan suatu faktor penting yang mempengaruhi seleksi alam maupun buatan yang dilakukan oleh manusia seperti mengeksploitasi sumberdaya hayati laut tersebut sesuai kebutuhannya. Tingkat keragaman genetik yang tinggi pada suatu populasi cenderung memiliki peluang hidup yang lebih baik (Basyuni et al., 2012). Respon terhadap perubahan lingkungan akan lebih beragam, karena memiliki berbagai macam gen dalam satu populasi. Beberapa studi menunjukkan bahwa karakteristik genetik suatu populasi ikan di alam pada umumnya menunjukkan adanya heterogenitas spasial, bahkan pada jarak yang sangat dekat (Smith \& Chesser, 1981).

Keragaman genetik dalam suatu populasi mulai menjadi subjek penelitian pada akhir abad ke-19. Tahun 1990-an, menjadi masa awal perkembangan teknologi dalam penelitian keragaman genetik menggunakan penanda genetik untuk mengidentifikasi struktur stok dan keragaman genetik dalam suatu populasi. Seiring dengan semakin berkembangnya teknologi yang berbasis penanda DNA maka penanda mikrosatelit merupakan penanda molekular yang berkembang lebih akhir (Sembiring et al., 2016). Dalam biologi perikanan, untuk mendeteksi keragaman genetik pada masing-masing individu ikan membutuhkan penanda genetik. Menurut Park \& Moran (1994), penanda molekul genetik dapat dikategorikan dalam 2 jenis, yaitu penanda DNA inti sel, dan DNA mitokondria (mtDNA). Penanda DNA inti seperti RAPDs (random amplified polymorphic DNA), AFLPs (amplified fragment length polymorphisms), VNTRs (variable number of tandem repeats loci): minisatellites, microsatellites, dan SNPs (single nucleotide polymorphisms). Penanda DNA mitokondria adalah penanda DNA yang diwarisi secara maternal, menunjukkan tingkat mutasi yang tinggi, dan tidak bergabung kembali sehingga mereka memiliki seperempat ukuran populasi efektif genetik (Ne) dari penanda inti (Ferguson \& Danzmann, 1998). Salah satu keunggulan utama pada penanda mikrosatelit adalah kodominan (heterozigot dapat dibedakan dari homozigot), tingkat polimorfisme yang sangat tinggi, dan range ukuran yang pendek (O'Connell \& Wright, 1994). Sedangkan kekurangan metode ini adalah sering terdapat shadow bands/pita DNA samar pada proses elektroforesis, kemunculan null alleles (Zardoya et al., 1996).

Kelompok tuna neritik adalah penyumbang volume hasil tangkapan terbesar kedua (41\%) di WPP-RI 572, setelah tuna tropis. Estimasi total hasil tangkapan tuna neritik secara nasional mencapai 474.428 ton pada tahun 2016, adapun hasil tangkapan yang berasal dari perairan Samudera Hindia Wilayah Pengelolaan Perikanan (WPP) 573 mencapai 64.477 ton atau $13,59 \%$ dari total hasil tangkapan tuna neritik secara nasional. Tongkol krai (Auxiz thazard) mendominasi hasil tangkapan dalam kurun 10 tahun terakhir, dengan rata-rata hasil tangkapan 3.904 ton/tahun, disusul oleh tongkol komo (Euthynnus affinis) dan tongkol abu-abu (Thunnus tonggol) (1.588 ton/tahun dan 1.332 ton/tahun) (BPS, 2017). Alat tangkap yang digunakan oleh nelayan Indonesia untuk mengeksploitasi ikan tongkol umumnya adalah pukat cincin (purse seine), jaring insang hanyut, (drifting gillnet), huhate (pole and line) dan pancing ulur (hand lines) (Widodo et al., 2014).

Penelitian ini bertujuan untuk mengetahui suhu dan waktu optimum penempelan 2 penanda DNA mikrosatelit pada proses amplifikasi DNA (PCR). Dengan diperolehnya informasi waktu dan suhu optimum dapat meningkatkan akurasi dalam proses pembacaan hasil PCR yang akan diperlukan dalam analisis selanjutnya seperti mencari nilai keragaman genetik suatu populasi ikan, karena produk amplifikasi yang kurang spesifik dan kurang optimum dapat menyulitkan dalam proses analisis .Hal ini disebabkan reaksi dalam proses amplifikasi atau PCR sangat sensitive terhadap sejumlah parameter seperti suhu dan waktu penempelan (annealing) penanda DNA saat amplifikasi.

\section{BAHANDANMETODE}

Analisis genetik dilaksanakan terhadap contoh jaringan (daging) dari species tongkol lisong (Auxis rochei) dan tongkol krai (Auxis thazard) (Gambar 1.). Sampel dikumpulkan di lokasi pendaratan ikan di Palabuhan Ratu, Jawa Barat. Representasi sampel masing-masing lokasi adalah 15-20 ekor. Sampel yang berupa jaringan daging berukuran kecil $(1 \times 1 \times 1 \mathrm{~cm})$ disayat di bagian tubuh dekat pangkal ekor (Gambar 2.); Sampel daging diambil pada bagian dekat ekor (Gambar 3). karena jumlah DNA yang lebih banyak pada jaringan otot yang aktif bergerak, sehingga diharapkan dapat diperoleh ekstrak DNA dengan konsentrasi tinggi yang diekstrak dari jaringan otot (Marwayana, 2015). Sample jaringan kemudian dipreservasi dalam vial yang sudah diisi larutan alkohol absolut. 


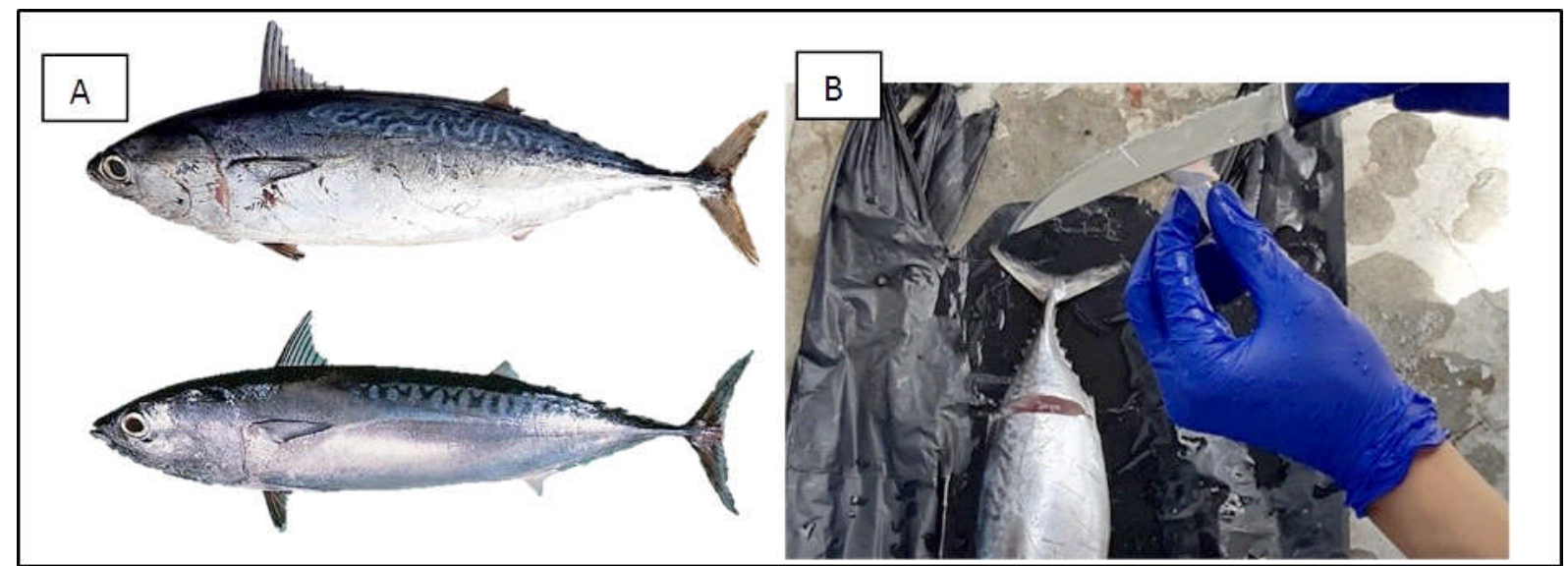

Gambar 1. A. ikan tongkol krai (atas) dan lisong (bawah) yang didaratkan di PPN Palabuhanratu, Jawa Barat. B. cara pengambilan sampel daging ikan.

Figure 1. A. Frigate tuna (top) and Bullet tuna (bottom) sample landed in Palabuhanratu national fishing port, West Java. B. fish sample cutting technique.

\section{Ekstraksi DNA}

Ekstraksi DNA 'DNeasy Spin Column' diawali dengan tube 1,5 ml diberi label, kemudian sampel (daging) ukuran 25-30 mg ditempatkan pada tube 1,5 ml. Kemudian ditambahkan $180 \mu l$ buffer ATL dan $20 \mu l$ proteinase K, lalu sampel digerus menggunakan pestle (gunakan pestle yang berbeda untuk setiap perlakuan sampel). Heating block atau waterbath $56^{\circ} \mathrm{C}$ dipanaskan terlebih dahulu. Kemudian sampel divortex dan diinkubasi di shaker heater pada suhu $56^{\circ} \mathrm{C}$ selama 1 jam, kemudian divortex kembali. Kemudian ditambahkan $200 \mu l$ Buffer AL dan $200 \mu l$ ethanol (96-100\%), divortex 15 detik lalu disentrifus pada 6000 x g (8000 rpm) selama 1 menit. Larutan supernatant dipipet dan dimasukkan ke dalam DNeasy Mini spin column yang ditempatkan dalam $2 \mathrm{ml}$ collection tube dan disentrifus pada 6000 x g $(8000 \mathrm{rpm})$ selama 1 menit. DNeasy Mini spin column ditempatkan pada $2 \mathrm{ml}$ collection tube yang baru, ditambahkan $500 \mu l$ Buffer AW1, disentrifus pada 6000 x g (8000 rpm) selama 1 menit. Collection tube dibuang. DNeasy Mini spin column ditempatkan ke dalam $2 \mathrm{ml}$ collection tube yang baru, ditambahkan $500 \mu l$ Buffer AW2, disentrifus pada 20,000 x g (14,000 rpm) selama 3 menit untuk mengeringkan membran DNeasy. Collection tube dibuang. DNeasy Mini spin column ditempatkan ke dalam tube $1,5 \mathrm{ml}$ baru, kemudian ditambahkan $200 \mu l$ Buffer AE dan dimasukkan ke dalam DNeasy membrane. Diinkubasi pada suhu ruang selama 5 menit dan disentrifus selama 1 menit pada $6000 \mathrm{x}$ $\mathrm{g}(8000 \mathrm{rpm})$ untuk proses elusi. DNA hasil elusi dapat langsung digunakan untuk proses PCR atau simpan pada suhu $-20^{\circ} \mathrm{C}$ atau $-80^{\circ} \mathrm{C}$ untuk penyimpanan lama. Konsentrasi hasil ekstraksi dapat langsung diketahui menggunakan IMPLEN Nanophotometer N50.(Lampiran 1.)

\section{Optimasi Amplifikasi}

Optimasi produk PCR dilakukan di Laboratorium Genetik Loka Riset Perikanan Tuna Bali. Amplifikasi pada inti sel DNA dilakukan menggunakan primer DNA mikrosatelit Aro2-38 (Forward: FAM 5'-CTG ACC AAC CAG TGC GAG GTGA-3' Reverse: 5'-GCAGTAATACAT TAAAGG AAT AAA TCA GAC CAC A-3'), (Catanese $e t$ al., 2007). Kriteria yang umum digunakan untuk merancang primer yang baik adalah bahwa primer sebaiknya berukuran $18-25$ basa, mengandung $50-60 \% \mathrm{G}+\mathrm{C}$ dan untuk kedua primer tersebut sebaiknya sama. Pada penelitian jumlah basa $\mathrm{G}+\mathrm{C}$ pada lokus Aro3-38 adalah 69 basa, atau sekitar $41.5 \%$ dari total urutan basa. Proses amplifikasi PCR menggunakan MyTaq HS Red Mix sebanyak 12,5 $\mu l$ dimasukkan ke dalam tabung PCR, kemudian ditambahkan $2 \mu l$ NFW (Nuclease-Free Water), $1 \mu l$ primer F, $1 \mu l$ primer R (konsentrasi $20 \mu M$ ) dan 4 $\mu l$ DNA template (konsentrasi 150-200 ng). Tabung PCR tersebut dimasukkan ke dalam mesin penyiklus DNA (Labcycler-Sensoquest). Konfigurasi suhu amplifikasi yang digunakan adalah sebagai berikut: fase pradenaturasi $\left(1\right.$ menit pada suhu $\left.95^{\circ} \mathrm{C}\right)$, denaturasi $(15$ detik pada suhu $\left.95^{\circ} \mathrm{C}\right)$, penempelan primer $(15$ dan 30 detik dengan 12 macam suhu berbeda yaitu : $52^{\circ} \mathrm{C} ; 52,8^{\circ} \mathrm{C} ; 54^{\circ} \mathrm{C}$; $55,5^{\circ} \mathrm{C} ; 57,2^{\circ} \mathrm{C} ; 59,1^{\circ} \mathrm{C} ; 60,9^{\circ} \mathrm{C} ; 62,8^{\circ} \mathrm{C} ; 64,5^{\circ} \mathrm{C} ; 65,9^{\circ} \mathrm{C} ; 67,2^{\circ} \mathrm{C}$ dan $\left.68^{\circ} \mathrm{C}\right)$, pemanjangan fragmen (10 detik dengan suhu $72^{\circ} \mathrm{C}$ ). Semua siklus diulang sebanyak 34 kali. Waktu annealing yang biasa digunakan dalam PCR adalah $30-$ 45 detik. Semakin panjang ukuran primer, semakin tinggi temperaturnya. Kisaran temperatur penempelan yang digunakan adalah antara $36^{\circ} \mathrm{C}$ sampai dengan $72^{\circ} \mathrm{C}$, namun suhu yang biasa dilakukan itu adalah antara $50-60^{\circ} \mathrm{C}$ (Yuwono, 2006). 


\section{Elektroforesis}

Pembacaan produk PCR dengan metode elektroforesis kapiler menggunakan alat QIAxcel ScreenGel 1.6.0. screening cartridge yang memiliki resolusi $100 \mathrm{bp}-2.5 \mathrm{~kb}$ (Cat. No. 929553) dengan ketelitian 20bp. DNA alignment yang digunakan saat amplifikasi adalah $15 \mathrm{bp} / 5 \mathrm{~kb}$ (Cat. No. 929524).

\section{HASIL DAN BAHASAN Hasil}

Nilai rerata konsentrasi DNA yang berhasil diperoleh dari proses ekstraksi adalah $199.20 \mathrm{ng} / \mu \mathrm{l}$ pada ikan tongkol lisong dan $179.25 \mathrm{ng} / \mu$ pada ikan tongkol krai. Perbanyakan DNA tongkol lisong dan krai menggunakan primer Aro2-38. Motif pengulangan Lokus Aro2-38 adalah
(TTCTTC) ${ }_{9}$ (CTCTC)(TTCTC) $)_{9}$ Lokus ini juga memiliki jumlah alel 25, rentang ukuran alel 116-256 bp, dan memiliki suhu annealing $58^{\circ} \mathrm{C}$ (Catanese et al., 2007). Hasil amplifikasi seperti terlihat pada Gambar 2 merupakan amplifikasi sampel tongkol lisong dan krai menggunakan suhu $52-68^{\circ} \mathrm{C}$, sedang penempelan primer selama 15 detik dan 30 detik tertera pada Gambar 3.

Ikan tongkol krai tidak berhasil diamplifikasi pada semua suhu dengan waktu penempelan 15 detik. Pada percobaan amplifikasi kedua menggunakan waktu annealing primer 30 detik, kedua sampel tongkol dan lisong berhasil diamplifikasi pada beberapa suhu yang berbeda. Ikan tongkol krai berhasil diamplifikasi pada suhu $52-55,5^{\circ} \mathrm{C}$ dengan waktu annealing 30 detik, sedangkan pada tongkol lisong sampel berhasil diamplifikasi pada suhu $52-60,9^{\circ} \mathrm{C}$ pada waktu penempelan primer 15 dan 30 detik (Gambar 2 dan Tabel 1.).

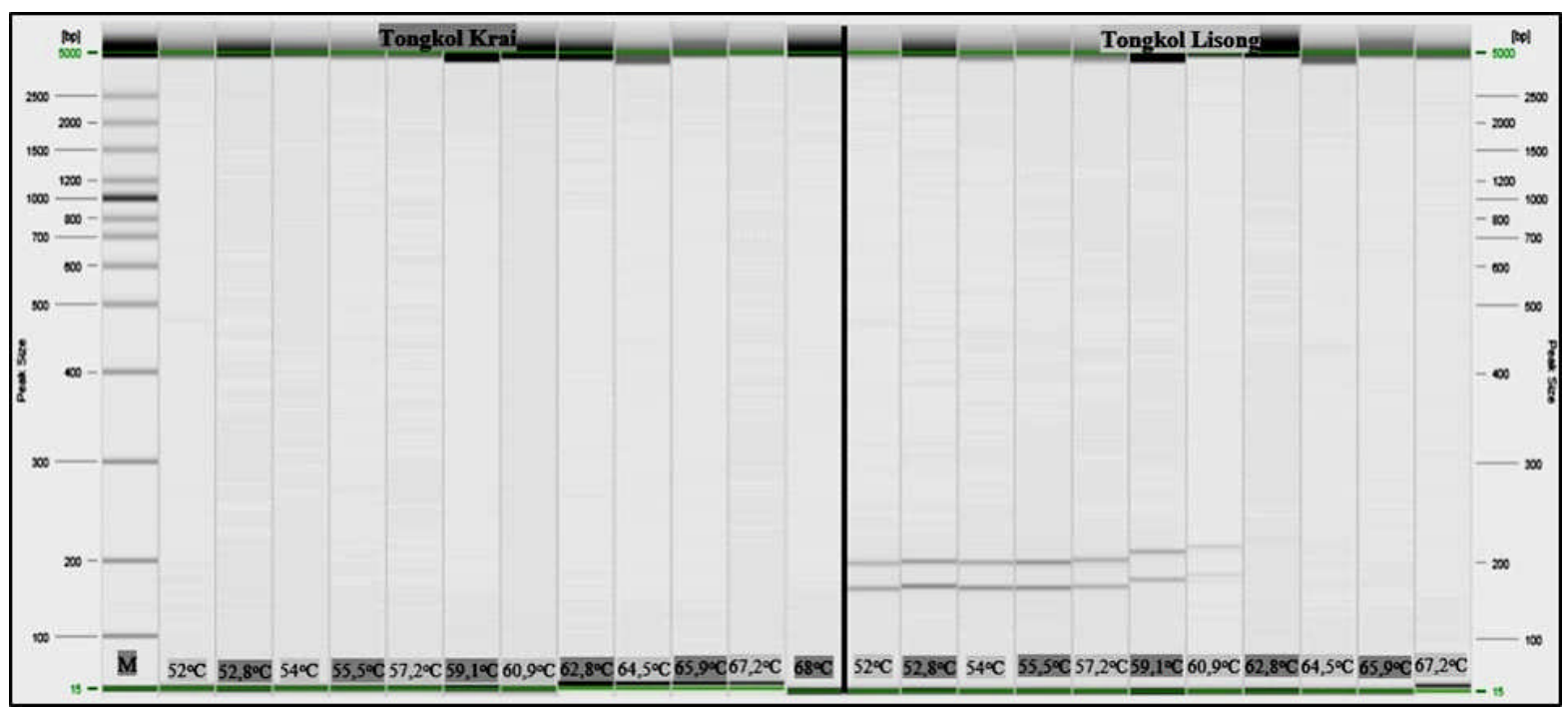

Gambar 2. Hasil Amplifikasi DNA mikrosatelit pada primer Aro2-38 pada waktu penempelan primer 15 detik. Figure 2. Microsatellite DNA amplification result on primer Aro2-38 with annealing time 15 seconds.

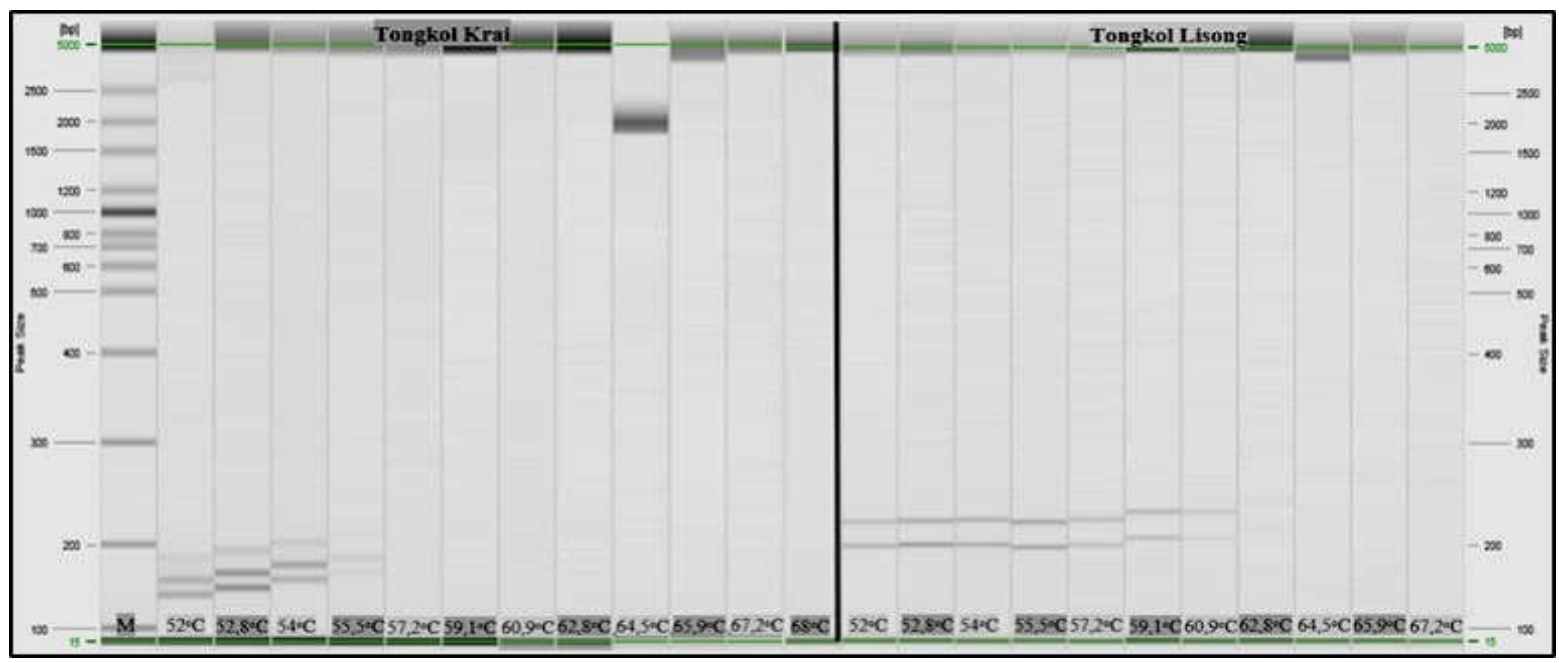

Gambar 3. Hasil Amplifikasi DNA mikrosatelit pada primer Aro2-38 pada waktu penempelan primer 30 detik. Figure 3. Microsatellite DNA amplification result on primer Aro2-38 with annealing time 30 seconds. 
Tabel 1. Hasil optimasi PCR sampel ikan tongkol lisong dan tongkol krai menggunakan primer mikrosatelit Aro2-38 Table 1. PCR optimization results on frigate dan bullet tuna using microsatellite primer Aro2-38

\begin{tabular}{cccccccccccccc}
\hline $\begin{array}{c}\text { Jenis } \\
\text { ikan }\end{array}$ & $\begin{array}{c}\text { Waktu } \\
\text { annealing }\end{array}$ & $\mathbf{5 2}$ & $\mathbf{5 2 , 8}$ & $\mathbf{5 4}$ & $\mathbf{5 5 , 5}$ & $\mathbf{5 7 , 2}$ & $\mathbf{5 9 , 1}$ & $\mathbf{6 0 , 9}$ & $\mathbf{6 2 , 8}$ & $\mathbf{6 4 , 5}$ & $\mathbf{6 5 , 9}$ & $\mathbf{6 7 , 2}$ & $\mathbf{6 8}$ \\
\hline $\begin{array}{c}\text { Tongkol } \\
\text { Krai }\end{array}$ & 15 detik & - & - & - & - & - & - & - & - & - & - & - & - \\
& 30 detik & $\sqrt{ }$ & $\sqrt{ }$ & $\sqrt{ }$ & $\sqrt{ }$ & - & - & - & - & - & - & - & - \\
& & & & & & & & & & & & & - \\
Tongkol & 15 detik & $\sqrt{ }$ & $\sqrt{ }$ & $\sqrt{ }$ & $\sqrt{ }$ & $\sqrt{ }$ & $\sqrt{ }$ & - & - & - & - & - & - \\
Lisong & 30 detik & $\sqrt{ }$ & $\sqrt{ }$ & $\sqrt{ }$ & $\sqrt{ }$ & $\sqrt{ }$ & $\sqrt{ }$ & - & - & - & - & - & - \\
\hline
\end{tabular}

Hasil amplifikasi yang berhasil kemudian dilakukan pengukuran jumlah pasang basa yang ditunjukkan pada saat elektroforesis. Pengukuran jumlah pasang basa dilakukan melalui metode elektroporesis kapiler menggunakan QIAxcel ScreenGel 1.6.0. screening cartridge. Gambar 4 menunjukkan pada salah satu sample yang berhasil diamplifikasi menunjukkan nilai 197 dan 223 pasang basa.

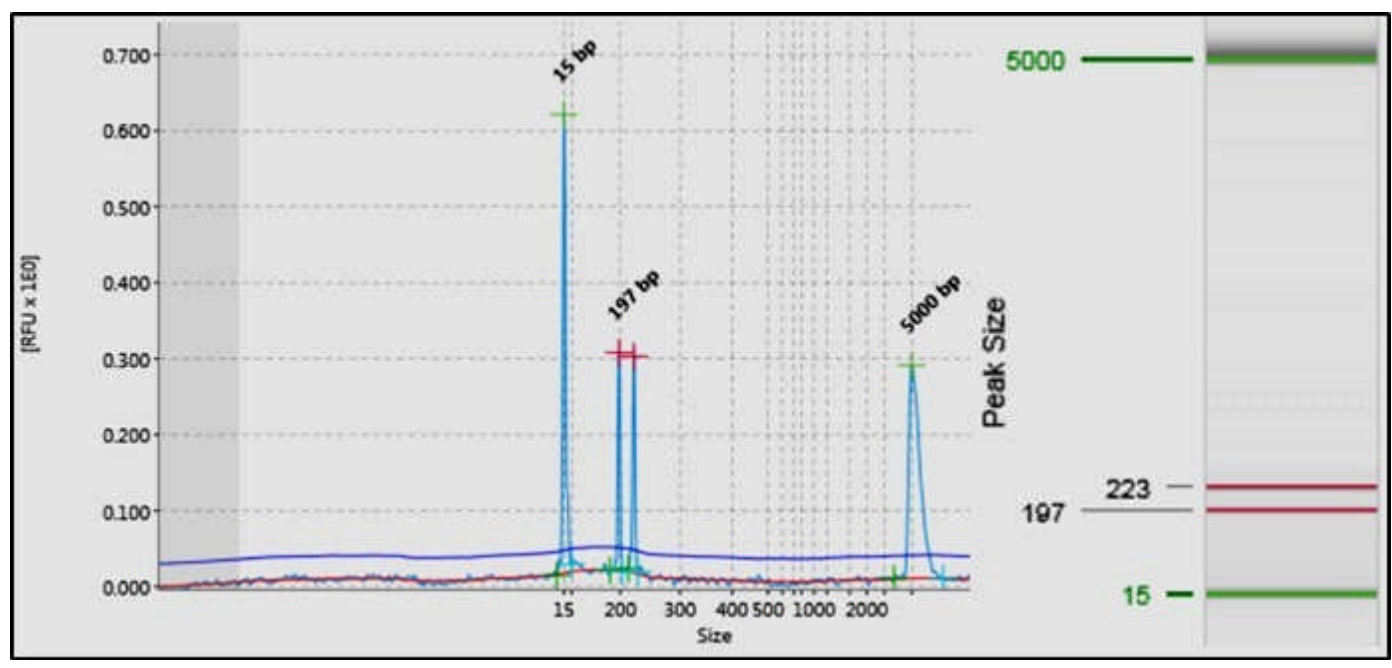

Gambar4. Ukuran basa ikan tongkol lisong pada waktu dan suhu penempelan 30 detik $55,5^{\circ} \mathrm{C}$.

Figure 4. Bullet tuna DNA size at a period and temperature 30 seconds and $55.5^{\circ} \mathrm{C}$.

\section{Bahasan}

Hasil visualisasi produk PCR setelah elektroforesis menunjukkan adanya pita DNA pada sampel yang berhasil diamplifikasi dari semua lokus, namun tidak semua sampel tersebut menunjukkan ketebalan pita DNA yang sama. Hal ini dapat disebabkan karena perbedaan konsentrasi DNA hasil ekstraksi di dalam template yang digunakan untuk PCR serta perbedaan konsentrasi DNA yang berhasil diamplifikasi (diperbanyak) (Pertiwi et al., 2015). Hasil Tidak munculnya pita DNA pada sampel tongkol krai dengan waktu penempelan 15 detik disebabkan kurangnya waktu yang dibutuhkan primer untuk menempel (lihat Tabel 1). Dapat dilihat bahwa sampel tongkol krai dengan waktu penempelan yang lebih lama yaitu 30 detik dapat menghasil pita DNA atau proses PCR yang berhasil. Hal ini dapat disebabkan karena primer Aro2-38 yang tergolong jenis primer yang berukuran panjang yaitu 166 bp (Catanese et al., 2007). Selain primer, urutan primer yang tidak komplementer juga menjadi salah satu faktor penentu keberhasilan PCR (Bucklin et al., 2011).
Suhu penempelan yang diatas $59,1^{\circ} \mathrm{C}$ tidak menghasilkan DNA target baik pada waktu penempelan 15 dan 30 detik. Suhu penempelan yang telalu tinggi menyebabkan terjadinya mutasi pada sisi penempelan primer yang akan menghasilkan null alel pada lokus tersebut. Menurut Wattier et al. (1998) null alel pada berbagai lokus mikrosatelit disebabkan oleh mekanisme amflipikasi diferensial yang berdasarkan varian ukuran alel. Karena sifat kompetitif pada proses PCR, alel DNA yang berukuran lebih kecil memiliki peluang lebih besar berhasil diamplifikasi daripada alel yang lebih panjang. Selain itu menurut Gagneux et al., 1997; Garcia et al., 1998 null alel lebih disebabkan karena kualitas atau kuantitas DNA hasil ekstraksi.

Ketika suhu dan waktu penempelan yang digunakan telah sesuai, maka primer akan menempel dengan tepat pada sisi annealing site dalam cetakan DNA. Menurut Yuwono (2006) setelah primer menempel, proses PCR akan dilanjutkan ke tahap pemanjangan untai DNA dimana semua siklus dilakukan sebanyak 30 kali. Alel DNA yang 
dihasilkan dapat dilihat seperti gambar 2. Dari gambar tersebut pita DNA tampak jelas yang menunjukkan bahwa suhu $52-60,9^{\circ} \mathrm{C}$ dan $52-54^{\circ} \mathrm{C}$ dan waktu pempelan 30 yang digunakan sudah mendekati sesuai. Modifikasi pada temperatur annealing merupakan salah satu cara yang umum dilakukan untuk meningkatkan keberhasilan dalam amplifikasi. Temperatur ini berpengaruh terhadap proses penempelan primer pada template DNA. Apabila temperatur annealing terlalu tinggi, primer tidak dapat menempel dengan baik pada template; sedangkan bila temperatur annealing rendah, maka primer akan menempel pada situs penempelan yang tidak spesifik yang kemudian akan menyebabkan teramplifikasinya fragmen lokus yang tidak diinginkan (Pratiwi et al., 2015).

Salah satu cara yang diyakini lebih akurat untuk mendapatkan informasi tentang unit stok adalah melalui pendekatan genetika populasi. Hasil PCR yang baik merupakan hal dasar yang harus diperoleh untuk dapat menghasilkan informasi variasi genetik sehingga didapatkan gambaran kekerabatan antar individu dalam suatu populasi. Informasi struktur populasi ini merupakan basis kajian stok dan opsi pengelolaannya agar pemanfaatannya dapat dilakukan secara berkelanjutan.

\section{KESIMPULAN}

Suhu dan waktu terbaik dalam proses PCR untuk studi keragaman genetik mikrosatelit tongkol krai dan lisong adalah $52-54^{\circ} \mathrm{C}$ dan $52-60,9^{\circ} \mathrm{C}$ dengan waktu penempelan/ annealing 30 detik. Perlu dilakukan pengamatan hasil amplifikasi menggunakan kapiler yang lebih akurat (High Resolution Cartridge) dan dilakukan uji lebih lanjut untuk mengetahui pola struktur populasi ikan tongkol lisong dan tongkol krai yang tertangkap di PPN Palabuhan Ratu. Setelah mengetahui nilai optimal pada tahap perbanyakan DNA yang akan digunakan, diharapkan dapat mempermudah langkah-langah selanjutnya dalam analisa keragaman/variasi genetik.

\section{PERSANTUNAN}

Tulisan ini merupakan bagian dari riset Riset Struktur, Parameter dan Potensi Stok Sumber Daya Ikan Tuna, Tongkol, dan Cakalang (TTC) di Samudera Hindia WPP 572 di Loka Riset Perikanan Tuna (LRPT) tahun 2019. Penulis mengucapkan terima kasih kepada analis Laboratorium Genetika Populasi LRPT, saudara Putu Viby Indriani.

\section{DAFTAR PUSTAKA}

Basyuni, M., Rahayu, S., \& Jayusman. (2012). Studi pendahuluan keragaman genetik spesies yang rentan johannesteijsmannia altifrons di Hutan Sikundur,
Sumatera Utara. FORESTA Indonesian Journal of Forestry. I (1), 7-11. ISSN: 2089-9890

BPS (Badan Pusat Statistik). (2017). Statistik Sumber Daya Laut dan Pesisir 2017 (No. 04320.1702; hlm. 310). Jakarta, Indonesia: Badan Pusat Statistik.

Bucklin, A., Steinke, D., \& Blanko-Bercial, L. (2011). DNA barcoding of marine metazoa. Annu. Rev.Mar.Sci. 3, 471-508. DOI: 10.1146/annurev-marine-120308-080950

Catanese, G., Infante, C., Crespo, A., Zuasti, E., Ponce, M., Funes, V., \& Manchado, M. (2007). Development and characterization of eight microsatellite markers in bullet tuna (Auxis rochei). Molecular ecology notes, 7(5), 842-844. DOI:10.1111/j.1471-8286.2007.01723.x

Ferguson, M. M., \& Danzmann, R. G. (1998). "Role of genetic markers in fisheries and aquaculture: useful tools or stamp collecting?". Canadian Journal of Fisheries and Aquatic Sciences, 55(7), 1553-1563. DOI: 10.1139/f98-096

Gagneux, P., Boesch, C., \& Woodruff, D.S. (1997). Microsatellite scoring errors associated with noninvasive genotyping based on nuclear dna amplified from shed hair. Mol Ecol, 6, 861-868. DOI: 10.1111/j.1365-294X.1997.tb00140.x

Garcia, F.J., Canonne, M., Quillet, E., Bonhomme, F., \& Chatain, B. (1998). The application of microsatellite markers to breeding programmes in the sea bass, Dicentrarchus labrax. Aquaculture, 159,303316.DOI:10.1016/S0044-8486(97)00188-9

Marwayana, O. N. (2015). Ekstraksi asam dioksiribonukleat (DNA) dari sampel jaringan otot. Oseana,XL(2), 1-9. ISSN:0216-1877

O’Connell, M. \& Wright, J. M. (1994). “Microsatellite DNA in fishes,". Reviews in Fish Biology and Fisheries,7(3),331-363. DOI: 10.1023/A:1018443912945

Park, L. K., \& Moran, P. (1994). "Developments in molecular genetic techniques in fisheries". Reviews in Fish Biology and Fisheries, 4(3), 272-299. DOI: 10.1007/ BF00042906

Pertiwi, N. P. D., Mahardika, I. G. N. K., \& Watiniasih, N. L. (2015). Optimasi Amplifikasi Dna Menggunakan Metode PCR (Polymerase Chain Reaction) Pada Ikan Karang Anggota Famili Pseudochromidae (Dottyback) Untuk Identifikasi Spesies Secara Molekular. Jurnal Biologi, 19(2), 1-5. DOI: 10.13140/RG.2.2.27883.34083 
Sembiring, S. B. M., Haryanti, Suwirya, K., Wardana, I. K., Sutarmat, T., \& Yudha H. T. (2016). Penggunaan Penanda Genetik Tumbuh Cepat Untuk Produksi Calon Induk Kerapu Sunu, Plectropomus Leopardus Dalam Program Seleksi. J. Ris. Akuakultur, 7(1), 1-9 DOI: 10.15578/jra.7.1.2012.1-9

Smith, M. H., \& Chesser, R.K. (1981). Rationali for Conserving Genetic Variation of Fish gen poll. Ecol. Bull. 23, 119 - 130. DOI: 10.2307/1444712https:// www.jstor.org/stable/1444712

Wattier, R., Engel, C.R., Saumitou-Laprade, P., \& Valero, M. (1998). Short Allele Dominance as a Source of Heterozygote Deficiency at Microsatellite Loci: Experimental Evidence at the Dinucleotide. Molecular ecology, 7(11), 1569-1573. DOI: 10.1046/j.1365294x.1998.00477.x
Widodo, A. A., Satria, F., \& Sadiyah, L. (2014). Status pemanfaatan dan pengelolaan sumber daya ikan tuna neritik di Samudera Hindia WPP 572 dan 573. J.Kebijak.Perik.Ind. 6(1), 23-28. DOI: 10.15578/ jkpi.6.1.2014.23-28

Yuwono, T. (2006). Teori dan Aplikasi Polymerase Chain Reaction, Panduan Eksperimen PCR untuk Memecahkan Masalah Biologi Terkini. Penerbit Andi, Yogyakarta

Zardoya, R., Vollmer, D.M., Craddock, C., Streelman, J. T., Karl, S. \& Meyer, A. (1996). "Evolutionary conservation of microsatellite flanking regions and their use in resolving the phylogeny of cichlid fishes (Pisces: Perciformes)". Proceedings of the Royal Society B: Biological Sciences, 263(1376), 1589-1598. DOI: 10.1098/rspb.1996.0233 
Lampiran 1. Bagan alir proses ekstraksi menggunakan DNeasy Blood \& Tissue Kit (50) (Qiagen, Cat\# 69504) Appendix 1. $\quad$ Flow chart of the extraction process using DNeasy Blood \& Tissue Kit (50) (Qiagen, Cat \# 69504)

\section{FLOW CHART PROSES EKSTRAKSI DNA}

A. PRE-TRATMENT SAMPEL

\begin{tabular}{|c|c|c|c|}
\hline $\begin{array}{l}\text { Tempatkan } 25-30 \mathrm{mg} \text { sampel } \\
\text { pada mikrotube } 2 \mathrm{ml}\end{array}$ & $\begin{array}{c}\text { Tambahkan } 200 \mu \mathrm{l} \text { buffer } \\
\text { ATL, lalugerus menggunakan } \\
\text { pinset }\end{array}$ & $\begin{array}{l}\text { Gunakan pinset yang } \\
\text { berbeda untuk setiap sampel }\end{array}$ & $\begin{array}{l}\text { Dilakukan proses purifikasi } \\
\text { menggunakan Dneasy \& Tissue } \\
\text { mini kit dengan mesin otomatisasi }\end{array}$ \\
\hline
\end{tabular}

B. EKSTRAKSI
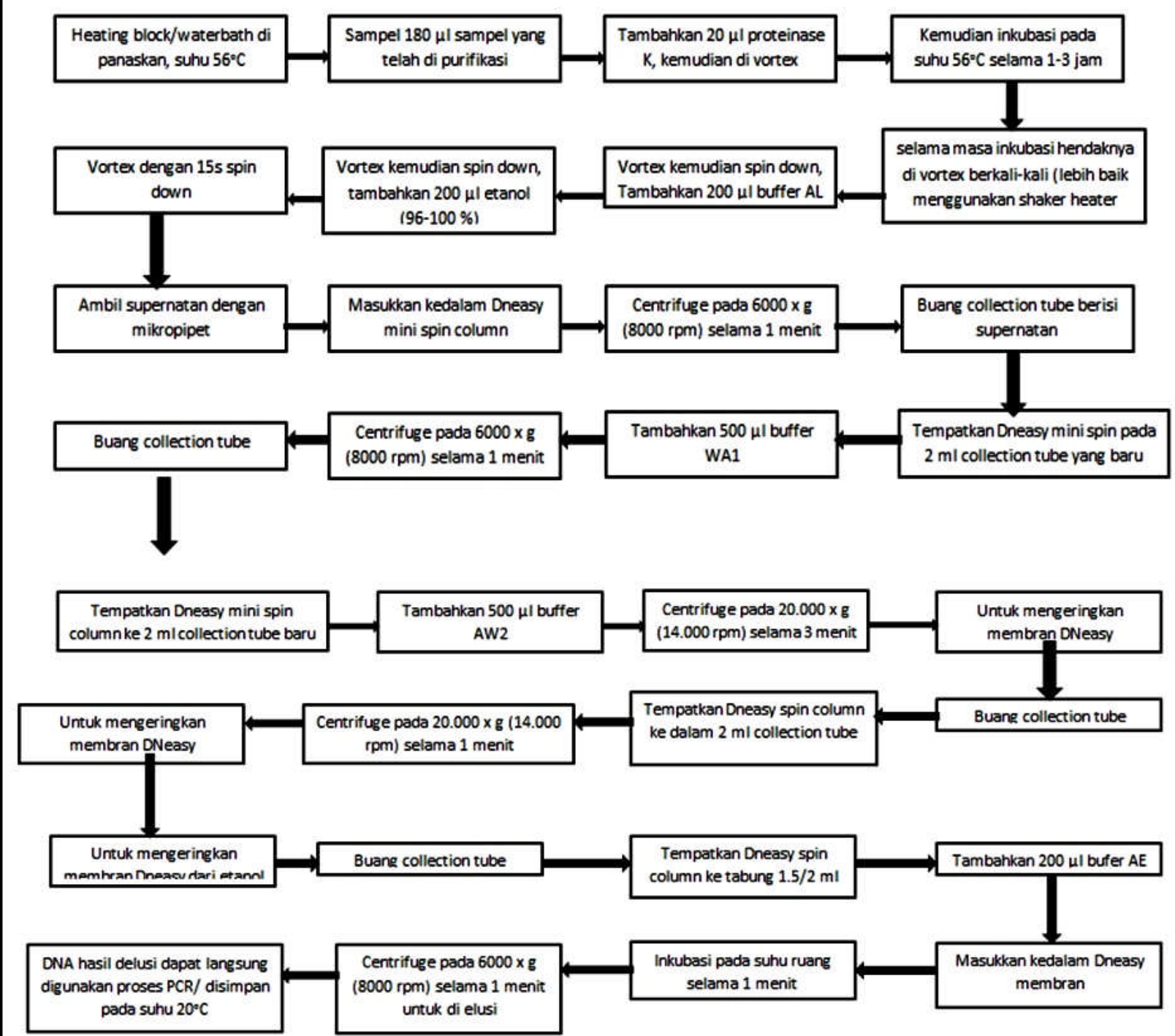